\title{
Pengembangan E-Modul Berbasis Mastery Learning Untuk Mata Pelajaran KKPI Kelas XI
}

\author{
Luh Putu Eka Diantari ${ }^{1)}$, Luh Putu Eka Damayanthi ${ }^{2)}$, Nyoman Sugihartini ${ }^{3)}$ \\ I Made Agus Wirawan ${ }^{4}$, \\ Jurusan Pendidikan Teknik Informatika \\ Fakultas Teknik dan Kejuruan \\ Universitas Pendidikan Ganesha \\ Singaraja, Bali \\ Email: ekadian121@gmail.com ${ }^{1}$, imade.aguswirawan@undiksha.ac.id ${ }^{2),}$, \\ ekadamayanthi@undiksha.ac.id ${ }^{3)}$, sugihartini@undiksha.ac.id ${ }^{4)}$
}

\begin{abstract}
Abstrak
Abstrak-Tujuan penelitian ini adalah: (1) Untuk mengembangkan E-Modul Berbasis Mastery Learning Pada Mata Pelajaran KKPI Kelas XI SMKN 1 Sawan, (2) Untuk mengetahui respon guru dan siswa terhadap Pengembangan E-Modul Berbasis Mastery Learning Pada Mata Pelajaran KKPI Kelas XI SMKN 1 Sawan. Jenis penelitian yang digunakan dalam penelitian ini adalah penelitian dan pengembangan (Research and Development) dengan model pengembangan PLOMP. Subjek penelitian ini yaitu siswa kelas XI di SMKN 1 Sawan tahun ajaran 2017/2018. Untuk mengetahui respon guru dan siswa terhadap e-modul KKPI diperoleh dengan menggunakan metode angket. Hasil penelitian menunjukkan bahwa: (1) Hasil rancangan dan realisasi e-modul berbasis model mastery learning pada mata pelajaran KKPI untuk siswa kelas XI di SMKN 1 Sawan dinyatakan berhasil diterapkan berdasarkan beberapa uji yang dilakukan. (2) Hasil analisis data respon guru menunjukkan rata-rata skor respon sebesar 45, jika dikonversikan ke dalam tabel penggolongan respon maka termasuk pada kategori sangat positif. Sedangkan untuk respon siswa terhadap pengembangan emodul didapatkan rata-rata skor respon sebesar 65,70 , jika dikonversikan ke dalam tabel penggolongan respon siswa termasuk pada kategori positif
\end{abstract}

Kata Kunci: E-Modul, KKPI, Mastery Learning

\begin{abstract}
Abstract- The aims of this research are: (1) To develop e-modul mastery learning teaching model of KKPI toward XI grade students at SMKN 1 Sawan, (2) To know both students and teachers response toward the development to realitation e-modul mastery learning teaching model of KKPI toward XI grade students at SMKN 1 Sawan. The design of this research was R\&D (research and development) research design accompanied with the development model of PLOMP. The subject of this research was all XI grade students at SMKN 1 Sawan academic year 2017/2018. In order to know both teachers and students response toward the e-modul $\mathrm{KKPI}$, the researcher used questionnaire. This research shows that: (1) the development of realitation e-modul mastery learning teaching model of KKPI toward XI grade students at SMKN 1 Sawan have been successfully realitation looking at several tests have been done by the researcher. (2) Based on the analysis of the data of teacher's response score of 45, if this converts into table of response categorization, it belongs to very positive category. Furthermore, based on the analysis of the data of students' response, on the other hand, shows the mean score of 65,70 . If it is converted into table of response categorization, it belongs to positive category.
\end{abstract}

Keywords: E-Modul, KKPI, Mastery Learning 


\section{PENDAHULUAN}

Media pembelajaran adalah segala sesuatu yang dapat menyalurkan pesan, dapat merangsang pikiran, perasaan, dan kemauan peserta didik [1]. Media merupakan perantara antara guru dan siswa dalam berkomunikasi. Tanpa media, komunikasi tidak akan terjadi dan proses pembelajaran sebagai proses komunikasi juga tidak akan bisa berlangsung secara optimal. Saat ini terdapat berbagai media pembelajaran yang diterapkan di sekolahsekolah, diantaranya penggunaan media pembelajaran dalam bentuk LKS dan powerpoint. Media pembelajaran tersebut diterapkan hampir di seluruh sekolah SMK. Salah satu diantaranya ialah SMKN 1 Sawan sebagai sekolah menengah kejuruan yang merupakan sekolah pariwisata berbasis teknologi informasi dan bisnis manajemen.

SMKN 1 Sawan merupakan sekolah menengah kejuruan yang terletak di Desa Menyali, Kec. Sawan, Kab. Buleleng. Kurikulum yang diterapkan disekolah ini adalah kurikulum KTSP. Dalam kurikulum tersebut terdapat beberapa program yang diterapkan, salah satunya ialah program prakerin untuk kelas XI. Prakerin merupakan praktek kerja industri yang diwajibkan untuk sekolah menengah kejuruan. Prakerin dilakukan di perusahaan atau dunia usaha/dunia industri selama lima bulan, selama itu proses belajar mengajar tidak bisa dilakukan dengan tatap muka. Sekolah mengharuskan siswa melaksanakan prakerin untuk memenuhi penilaian pada mata pelajaran produktif dengan produk laporan prakerin, sedangkan untuk memenuhi nilai normatif dan adaptif siswa harus mengerjakan tugas yang diberikan selama melaksanakan prakerin. Dari wawancara yang telah dilakukan terhadap guru pengampu mata pelajaran KKPI kelas IX terdapat permasalahan proses pembelajaran terkait hal itu. Ketika prakerin berlangsung guru tidak bisa menjelaskan materi kepada siswa, dalam keadaan tersebut siswa dituntut untuk belajar mandiri. Dalam pembelajaran mandiri, sarana pembelajaran yang digunakan siswa selama prakerin hanya berupa website sekolah. Guru hanya memberikan materi dan tugas kepada siswa melalui website sekolah dalam bentuk pdf yang diintregasikan pada menu download beranda web. Hal itu cukup memudahkan siswa untuk mengakses tugas yang diberikan. Namun website tersebut tidak menyediakan forum diskusi untuk komunikasi siswa selama prakerin. Sehingga, siswa yang mengalami kesulitan tidak bisa bertanya apabila ada hal yang tidak dimengerti dari materi dan tugas yang diberikan. Ini mengakibatkan siswa malas mengerjakan tugas. Dengan ini, guru tidak bisa mengontrol proses belajar siswa. Guru tidak bisa memastikan kejujuran siswa dalam mengerjakan tugas. Sehingga proses belajar dan pemberian tugas sering dianggap hanya sebagai formalitas tanpa mengukur pemahaman atau kemampuan siswa itu sendiri.

Selain itu, karena tidak adanya buku pegangan untuk pembelajaran KKPI. Guru hanya menggunakan LKS dan sumber internet untuk mendapatkan bahan ajar. LKS hanya mencakup materi singkat dan terbatas. Bahan ajar atau materi yang dikirimkan guru dalam bentuk pdf tersebut hanya didapat dari sumber internet. Sehingga bahan ajar atau materi yang didapat tidak terstruktur dengan baik. Memang banyak materi yang terdapat di internet dan sumber lainnya mengenai KKPI. Namun hal itu belum sesuai dengan standar kompetensi atau kompetensi dasar pada kurikulum yang diberlakukan oleh sekolah itu sendiri. Pembelajaran mandiri dan satu arah tersebut membuat siswa tidak memiliki inisiatif untuk mencari sumber belajar lain. Siswa cenderung malas mencari sumber belajar lain dan hanya berpatokan pada materi yang diberikan oleh guru. Dari permasalahan tersebut dapat disimpulkan bahwa media pembelajaran yang digunakan belum mampu mengatasi 
permasalahan yang ada. Oleh karena itu dipandang perlu untuk membuatkan media pembelajaran terkait dengan pelaksanaan prakerin yang mengharuskan siswa untuk belajar mandiri dengan permasalahan sumber ajar yang ada dengan pengembangan e-modul berbasis mastery learning. Pengembangan e-modul dapat dipadukan dengan model pembelajaran yang dipandang mampu meningkatkan hasil belajar mahasiswa ${ }^{[2]}$. Pada penelitian ini modul elektronik disusun berbasis Mastery Learning. Mastery learning atau disebut dengan belajar tuntas adalah pencapaian taraf penguasaan minimal yang ditetapkan untuk setiap unit bahan pelajaran baik secara perseorangan maupun kelompok. Salah satu prinsip dari pendekatan Mastery learning adalah siswa belajar aktif. Prinsip ini memungkinkan siswa mendapatkan pengetahuan berdasarkan kegiatan-kegiatan yang dilakukannya sendiri dan mendorong siswa untuk bertanya apabila mengalami kesulitan, mencari buku atau sumbersumber lain untuk memecahkan persoalanpersoalan yang dihadapinya ${ }^{[3]}$. Dalam pelaksanaannya peserta didik memulai belajar dari topik yang sama pada waktu yang sama pula. Topik tersebut dibagi menjadi unit-unit. Siswa tidak bisa melanjutkan ke tahapan materi selanjutnya apabila belum tuntas pada unit pertama. Siswa yang telah tuntas pada unit pertama mendapat pengayaan sehingga mereka pun memulai mempelajari topik baru pada unit selanjutnya. Hal ini sesuai dengan karakteristik siswa serta karakteristik teknis pembelajaran selama prakerin yang mengharuskan siswa untuk belajar secara mandiri.

Pada penelitian ini e-modul berbasis mastery learning akan disusun dengan bantuan platform inovatif yaitu Schoology. Dengan adanya Schoology siswa dapat belajar secara online, berkolaborasi dengan rekan-rekan mereka dan dapat belajar secara mandiri sesuai dengan kurikulum KTSP. Adapun kelebihan dari Schoology dibanding platform yang lain diantaranya stay conneted, extend class time, manage on the go serta leverage iOS and android device. Kelebihan lain dari schoology ialah tersedianya fasilitas attandance labsensi, yang digunakan untuk mengecek kehadiran siswa, dan juga fasilitas analityc untuk melihat semua aktivitas siswa pada setiap course, assignment, discussion dan aktivitas lainnya. Dengan kelebihan fiturfitur tersebut guru bisa memastikan kegiatan pembelajaran siswanya.

Berdasarkan penelitian sebelumnya terkait dengan penelitian e-modul, didapatkan beberapa hasil penelitian yang relevan dengan penelitian pengembangan e-modul, yaitu Priatna (2017) dengan Pengembangan E-Modul Berbasis Model Pembelajaran Project Based Learning Pada Mata Pelajaran Videografi untuk Siswa Kelas X Desain Komunikasi Visual di SMK Negeri 1 Sukasada menggunakan tahapan model project based learning sudah dinyatakan berhasil diterapkan. Secara umum siswa terlihat antusias dan lebih aktif selama proses pembelajaran berlangsung, belajar tuntas (mastery learning) menyatakan pendekatan belajar tuntas (mastery learning) dapat meningkatkan kualitas pembelajaran ${ }^{[4]}$. Pengembangan berbasis Schoology menyatakan bahwa media e-learning berbasis schoology terbukti efektif secara signifikan dapat meningkatkan hasil belajar mata pelajaran Bahasa Indonesia kelas X semester I tahun pelajaran 2014/2015 di SMA Negeri 4 Singaraja ${ }^{[5]}$. Hal ini dibuktikan berdasarkan hasil uji dari nilai rata-rata hasil belajar siswa.

Berdasarkan uraian di atas, maka perlu dikembangkan suatu bahan ajar dalam hal ini berupa modul elektronik berbasis model pembelajaran mastery learning. Terkait hal ini, peneliti melakukan pengembangan emodul dalam penelitian dengan judul "Pengembangan E-Modul Berbasis Mastery Learning Pada Mata Pelajaran KKPI ( Studi Kasus : Siswa Kelas XI SMKN 1 Sawan )".

\section{A. KKPI}

\section{KAJIAN TEORI}

KKPI adalah singkatan dari Keterampilan Komputer dan Pengelolaan Informasi. KKPI 
adalah salah satu mata pelajaran adaptif yang diberikan kepada semua bidang keahlian di Sekolah Menengah Kejuruan. KKPI diterapkan di Sekolah Menengah Kejuruan yang masih menggunakan kurikulum KTSP ${ }^{[6]}$. Sedang pada SMU dan SMP dikenal dengan nama mata pelajaran TIK. Mata pelajaran ini sebagai dasar pengetahuan tentang teknologi informasi agar siswa bisa mengikuti perkembangan global melalui teknologi.

B. Model pembelajaran mastery learning.

Model belajar tuntas (Mastery Learning) adalah pencapaian taraf penguasaan minimal yang ditetapkan untuk setiap unit bahan pelajaran baik secara perseorangan maupun kelompok, dengan kata lain apa yang dipelajari siswa dapat dikuasai sepenuhnya ${ }^{[2]}$. Model belajar tuntas (Mastery Learning) ini dikembangkan oleh John B. Caroll (1971) dan Benjamin Bloom (1971) ${ }^{[7]}$. Di Indonesia model belajar tuntas (Mastery Learning) ini dipopulerkan oleh Badan Pengembangan Penelitian Pendidikan dan Kebudayaan. Belajar tuntas menyajikan suatu cara yang sistematik, menarik dan ringkas untuk meningkatkan unjuk kerja siswa ke tingkat pencapaian suatu pokok bahasan yang lebih memuaskan. Pembelajaran tuntas adalah pola pembelajaran yang menggunakan prinsip ketuntasan secara individual agar kegagalan peserta didik dalam belajar dapat dikurangi. Strategi belajar tuntas menganut pendekatan klasikal tetapi sangat memperhatikan individual. Dalam proses pembelajaran, meskipun kegiatan belajar ditujukan kepada sekelompok peserta didik (klasikal), tetapi tetap mengakui dan melayani perbedaan individual peserta didik dengan sebaik baiknya. Dengan demikian penerapan pembelajaran tuntas memungkinkan berkembangnya potensi masing-masing peserta didik secara optimal. Dasar pemikiran dari belajar tuntas dengan pendekatan individual ialah adanya pengakuan terhadap perbedaan individual masing-masing peserta didik.

Tolak ukur yang digunakan pada pencapaian hasil belajar dengan pendekatan tersebut adalah tingkat kemampuan siswa per orang, bukan per kelas. Dengan demikian, siswa yang memiliki tingkat kecerdasan atau penguasaan pengetahuan dan keterampilan diatas rata-rata kelas, siswa yang bersangkutan berhak memperoleh pengayaan materi atau melanjutkan ke unit kompetensi selanjutnya, sebaliknya apabila siswa tersebut belum mampu mencapai standar kompetensi sesuai standar ketuntasan yang diharapkan maka siswa tersebut harus mengikuti program perbaikan (remedial) materi.

Model pembelajaran mastery learning memiliki 5 tahapan pembelajaran yaitu orientasi, penyajian, latihan terstruktur, latihan terbimbing, dan latihan mandiri.

\section{Modul Ajar}

Modul ajar adalah bahan ajar yang disusun secara sistematis dan menarik yang mencakup isi materi, metode dan evaluasi yang dapat digunakan secara mandiri untuk mencapai kompetensi yang diharapkan ${ }^{[8]}$. Modul ajar adalah suatu paket pengajaran yang memuat satu unit konsep daripada bahan pelajaran ${ }^{[9]}$. Pengajaran modul merupakan usaha penyelanggaraan pengajaran individual yang memungkinkan siswa menguasai satu unit bahan pelajaran sebelum dia beralih kepada unit berikutnya. Berdasarkan beberapa pengertian modul di atas maka dapat disimpulkan bahwa modul ajar adalah salah satu bentuk bahan ajar yang dikemas secara sistematis dan menarik sehingga mudah untuk dipelajari secara mandiri.

\section{E-Modul (Modul Elektronik)}

Modul elektronik merupakan versi elektronik dari sebuah modul yang sudah dicetak yang dapat dibaca pada komputer dan dirancang dengan software yang diperlukan. E-modul merupakan alat atau sarana pembelajaran yang berisi materi, metode, batasan-batasan dan Author surnames go here 3 cara mengevaluasi yang dirancang secara sistematis dan menarik untuk mencapai kompetensi yang diharapkan sesuai dengan tingkat kompleksitasnya secara elektronik. Modul 
elektronik dapat didefinisikan sebagai sebuah bentuk penyajian bahan belajar mandiri yang disusun secara sistematis ke dalam unit pembelajaran terkecil untuk mencapai tujuan pembelajaran tertentu, yang disajikan dalam format elektronik, dimana setiap kegiatan pembelajaran di dalamnya dihubungkan dengan link - link sebagai navigasi yang membuat peserta didik menjadi interaktif dengan program, dilengkapi dengan penyajian video tutorial, animasi dan audio untuk memperkaya pengalaman belajar ${ }^{[10]}$. Modul elektronik yang dapat diakses oleh siswa mempunyai manfaat dan karakteristik yang berbeda beda. Jika ditinjau dari manfaatnya media elektronik sendiri dapat menjadikan proses pembelajaraan lebih menarik, interaktif, dapat dilakukan kapan dan dimana saja dapat meningkatkan kualitas pembelajaran [11]

\section{E. Schoology}

Schoology merupakan salah satu platform inovatif yang dibangun berdasarkan inspirasi dari media sosial facebook dengan tujuan untuk kepentingan pendidikan. Platform ini dikembangkan pada tahun 2009 di New York. Platform Schoology dirancang Oleh Jeremy Friedman, Ryan Hwang dan Tim Trinidad. Komunitas Global Schoology diadopsi dari 12 juta orang di seluruh 130 negara di dunia. Schoology adalah Learning Managemen System (LMS) untuk K-12 sekolah, lembaga pendidikan tinggi, dan perusahaan yang memungkinkan pengguna untuk membuat, mengelola, dan berbagi konten dan sumber daya. Schoology juga dikenal sebagai Content Management System (CMS) atau lingkungan belajar virtual (VLE), platform berbasis cloud menyediakan alat untuk mengelola setiap kelas atau lingkungan blended learning. Schoology merupakan media dimana orang tua, siswa dan guru saling terhubung sama lain. Dalam sistem, orang tua akan mengetahui penilaian dalam hal ini yaitu kemajuan anak-anaknya dalam proses pembelajaran yang direkam oleh guru.

\section{F. Kerangka Berpikir}

Berdasarkan latar belakang masalah dan kajian teori yang telah dipaparkan untuk meningkatkan kualitas hasil belajar siswa, media pembelajaran yang diterapkan harus sesuai dengan permasalahan yang ada. Program prakerin yang dilaksanakan tidak memungkinkan siswa dan guru melakukan pembelajaran secara langsung. Sedangkan pada akhir semester siswa harus mengikuti ujian akhir semester pada mata pelajaran tertentu. Sarana pembelajaran yang digunakan siswa selama prakerin hanya berupa website sekolah. Selain itu, karena tidak adanya buku pegangan untuk pembelajaran KKPI.
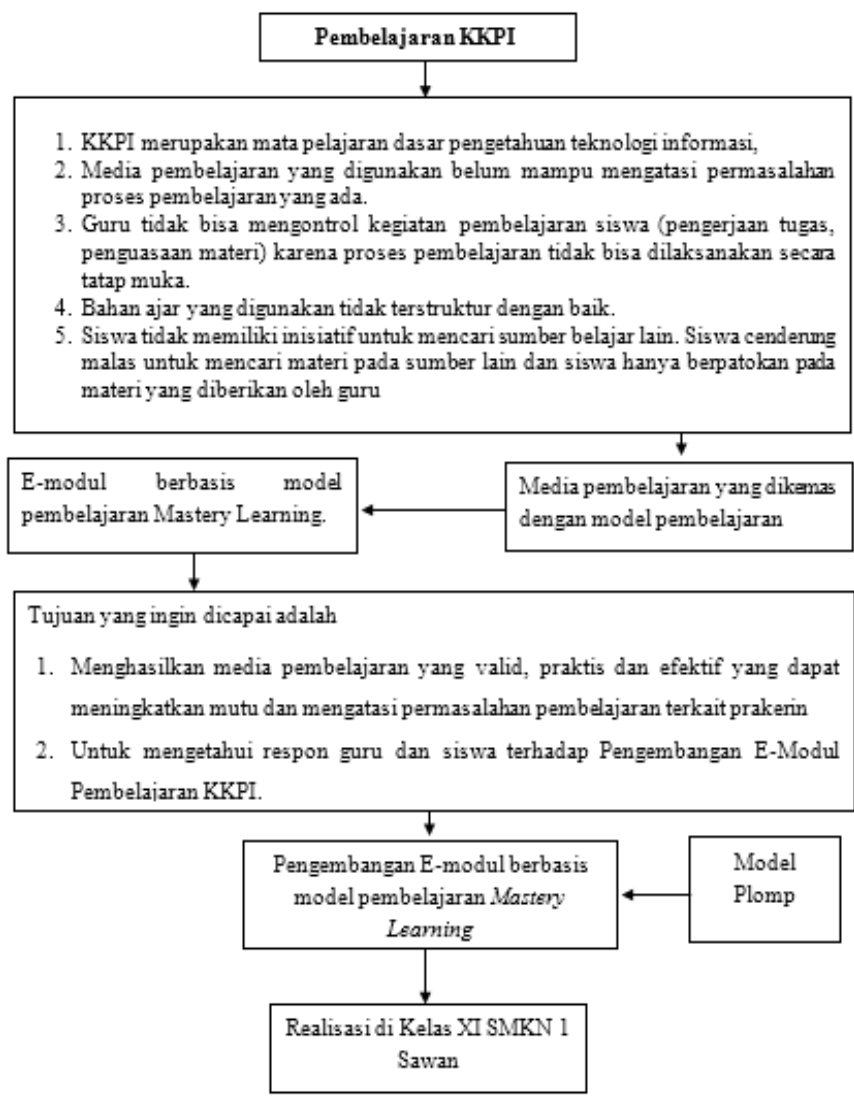

\section{Gambar 1. Kerangka Berpikir Pengembangan E-Modul}

Guru hanya menggunakan LKS dan sumber internet untuk mendapatkan bahan ajar. LKS hanya mencakup materi singkat dan terbatas. Bahan ajar atau materi yang 
dikirimkan guru dalam bentuk pdf tersebut hanya didapat dari sumber internet. Sehingga bahan ajar atau materi yang didapat tidak terstruktur dengan baik. Memang banyak materi yang terdapat di internet dan sumber lainnya mengenai $\mathrm{KKPI}$. Namun hal itu belum sesuai dengan standar kompetensi atau kompetensi dasar pada kurikulum yang diberlakukan oleh sekolah itu sendiri. Pembelajaran mandiri dan satu arah tersebut membuat siswa tidak memiliki inisiatif untuk mencari sumber belajar lain. Siswa cenderung malas untuk mencari sumber belajar lain dan siswa hanya berpatokan pada materi yang diberikan oleh guru.

Untuk itu diperlukanlah sebuah media pembelajaran untuk menunjang pembelajaran selama prakerin berlangsung. Salah satunya mata pelajaran yang akan dievaluasi ialah pembelajaran KKPI. Pelajaran KKPI merupakan mata pelajaran yang mempelajari tentang dasar teknologi informasi serta kebermanfaatannya dalam kehidupan sehari-hari. Permasalahan yang ada perlu solusi yang inovatif. Tentunya tidak semua permasalahan akan terselesaikan dengan solusi yang diajukan. Harapannya solusi yang ditawarkan mampu meminimalisir atau mengurangi permasalahan yang terjadi dan memberikan dampak positif terhadap proses pembelajaran selama prakerin berlangsung. Sehingga apa yang menjadi tujuan utama dalam pembelajaran bisa tercapai dengan optimal.

\section{A. Model Pengembangan}

\section{METODOLOGI}

Model penelitian merupakan dasar untuk mengembangkan produk yang akan dihasilkan. Penelitian ini menggunakan desain pengembangan model Plomp. Desain pengembangan model Plomp merupakan salah satu model desain sistematik dan tepat digunakan pada penelitian pengembangan pendidikan. Model plomp terdiri dari 5 fase. Yaitu fase investigasi awal (Prelimenary Investigation), fase desain (Design), fase realisasi (Realization /Construction), fase test, evaluasi, revisi (Test, Evaluation, Revision) dan fase implementasi (Implementation). Prosedur pengembangan akan memaparkan prosedur yang ditempuh oleh peneliti/pengembang dalam membuat produk. Model umum untuk memecahkan masalah bidang pendidikan yang dikemukakan (Plomp, 1997) yang selanjutnya disebut model Plomp, digambarkan sebagai berikut:

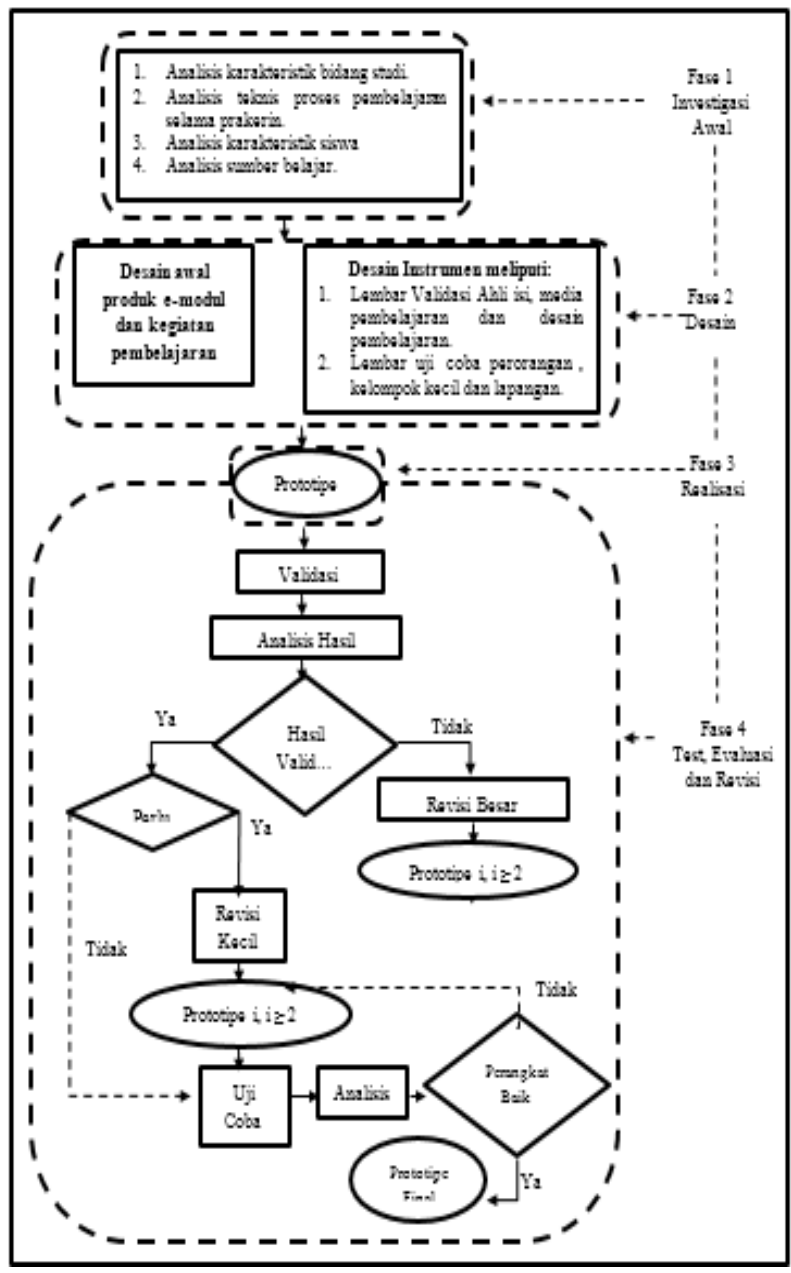

Gambar 2. Diagram Alur Fase Pengembangan

\section{B. Teknik Pengumpulan Data}

Data yang dikumpulkan untuk dianalisis bersifat kualitatif dan kuantitatif dalam penelitian ini, yaitu meliputi informasi sumber belajar, kevalidan e-modul dan respon siswa dan guru terhadap e-modul yang akan dikembangkan. Teknik pengumpulan data dapat dilihat pada Tabel 1. 
Tabel 1.Teknik Pengumpulan Data

\begin{tabular}{|c|c|c|c|}
\hline No & Jenis Data & Metode & Sumber Data \\
\hline 1 & $\begin{array}{l}\text { Informasi } \\
\text { tentang } \\
\text { Prakerin }\end{array}$ & Wawancara & $\begin{array}{l}\text { Guru yang } \\
\text { bertanggung } \\
\text { jawab pada teknis } \\
\text { prakerin }\end{array}$ \\
\hline 2 & $\begin{array}{l}\text { Informasi } \\
\text { terkait } \\
\text { permasalahan } \\
\text { pembelajaran }\end{array}$ & Waw & $\begin{array}{l}\text { Guru } \\
\text { pelajaran } \\
\text { kelas XI }\end{array}$ \\
\hline 3 & $\begin{array}{l}\text { Karakteristik } \\
\text { peserta didik }\end{array}$ & $\begin{array}{l}\text { - Angket } \\
\text { - Wawancar } \\
\text { a }\end{array}$ & \begin{tabular}{lr} 
Peserta & \multicolumn{2}{l}{ didik } \\
kelas XI & AP di \\
SMKN 1 Sawan \\
Singaraja & \\
$\begin{array}{ll}\text { Guru } \\
\text { pelajaran }\end{array}$ & mata \\
kelas XI & \\
\end{tabular} \\
\hline 4 & $\begin{array}{l}\text { Kevalidan } \\
\text { modul }\end{array}$ & Angk & $\begin{array}{l}\text { Ahli isi } \\
\text { pembelajaran, ahli } \\
\text { desain } \\
\text { pembelajaran, dan } \\
\text { ahli media } \\
\text { pembelajaran }\end{array}$ \\
\hline 5 & $\begin{array}{l}\text { Respon guru } \\
\text { dan peserta } \\
\text { didik }\end{array}$ & Angket & $\begin{array}{lr}\text { Guru } & \text { Mata } \\
\text { Pelajaran dan } \\
\text { peserta didik kelas } \\
\text { XI di SMKN } 1 \\
\text { Sawan }\end{array}$ \\
\hline
\end{tabular}

Pada kegiatan observasi guna mendapat informasi sumber belajar dan karakteristik pembelajar, digunakan jenis metode wawancara serta angket tertutup dan terbuka. Melalui metode wawancara dan angket ini peneliti mengetahui masalah yang terjadi pada proses pembelajaran terkait sumber belajar, materi, media, dan ketertarikan serta karakteristik siswa dalam pembelajaran KKPI.

Metode angket digunakan dalam kegiatan review dari ahli isi bidang studi, ahli desain pembelajaran, ahli media pembelajaran, uji coba perorangan, uji coba kelompok kecil, dan uji coba lapangan. Uji para ahli terdiri dari dua pilihan yaitu Sesuai dan Tidak Sesuai, sedangkan untuk uji coba perorangan, uji coba kelompok kecil, uji coba lapangan, dan uji respon terdiri dari lima pilihan, yaitu Sangat Setuju (SS), Setuju (S), Kurang Setuju (KS), Tidak Setuju (TS), dan Sangat Tidak Setuju (STS). Untuk skor pada angket uji coba dapat dilihat pada Tabel 2.

Tabel 2. Skor Pernyataan

\begin{tabular}{|c|c|c|}
\hline Alternatif & $\begin{array}{l}\text { Skor } \\
\text { Pernyataan } \\
\text { Positif }\end{array}$ & $\begin{array}{l}\text { Skor } \\
\text { Pernyataan } \\
\text { Negatif }\end{array}$ \\
\hline $\begin{array}{ll}\text { Sangat } & \text { Setuju } \\
\text { (SS) } & \end{array}$ & 5 & 1 \\
\hline Setuju (S) & 4 & 2 \\
\hline $\begin{array}{l}\text { Kurang Setuju } \\
\text { (KS) }\end{array}$ & 3 & 3 \\
\hline Setuju & 2 & 4 \\
\hline $\begin{array}{l}\text { Sangat Tidak } \\
\text { Setuju (SKS) }\end{array}$ & 1 & 5 \\
\hline
\end{tabular}

\section{TEKNIK ANALISIS DATA}

Analisis data pada penelitian pengembangan ini bertujuan untuk menjawab rumusan masalah dalam kesimpulan. Berikut ini merupakan teknik analisis data yang digunakan oleh peneliti, diantaranya yaitu :

1. Analisis data kevalidan Modul Ajar

Analisis data kevalidan e-modul dimaksudkan untuk mengetahui sejauh mana e-modul yang telah dibuat memenuhi kriteria berdasarkan penilaian validator yang ditunjuk dengan menggunakan lembar validasi ahli, hasil validasi ahli menjadi dasar dan pertimbangan dalam melakukan revisi

2. Analisis data respon guru dan siswa Analisis data respon guru dan siswa dimaksudkan untuk mengetahui bagaimana respon guru dan siswa terhadap e-modul yang dikembangkan 


\section{ANALISIS DATA KEVALIDAN E- MODUL}

Validasi e-modul diuji oleh ahli isi, ahli desain, ahli media, uji perorangan dan uji kelompok kecil, menganalisis respon guru dan siswa terhadap pengembangan emodul diuraikan sebagai berikut.

1. Validasi Ahli Isi

Validasi isi dapat diperoleh melalui ahli isi. Validasi ini bertujuan untuk mengetahui isi yang terkandung di dalam e-modul apakah sudah sesuai dengan konsep pengetahuan atau indikator yang ingin dicapai. Konsep pengetahuan atau indikator yang ingin dicapai dituangkan ke dalam beberapa kegiatan pembelajaran. Peneliti melibatkan guru yang mengajar mata pelajaran KKPI sebagai ahli karena mengetahui secara detail kegiatan pembelajaran yang dilakukan. Penilaian hasil dari uji ahli isi dihitung dengan Rumus Gregory. Gregory menurut mengembangkan teknik dalam pengujian isi yang sudah dikuantitatifkan ${ }^{[12]}$. Mekanisme perhitungan pengujian validitas isi menurut Gregory adalah sebagai berikut.

a. Para pakar yang dipercaya menilai instrument melakukan penilaian instrument perbutir.

b. Pengelompokan skala, sesuai dan tidak sesuai.

c. Hasil penilaian para pakar ditabulasi silang, misalnya untuk dua penilai seperti pada Tabel 3 .

Tabel 3. Tabulasi Uji Gregory

\begin{tabular}{|c|c|c|c|}
\hline & & \multicolumn{2}{|c|}{ PENILAI 1} \\
\hline & & $\begin{array}{l}\text { Tidak } \\
\text { Sesuai }\end{array}$ & Sesuai \\
\hline \multirow{2}{*}{$\begin{array}{l}\text { PENILAI } \\
\quad 2\end{array}$} & Tidak Sesuai & (A) & (B) \\
\hline & Sesuai & (C) & (D) \\
\hline
\end{tabular}

Perhitungan validitas isi dengan rumus
Validitas Isi $=\frac{\boldsymbol{D}}{\mathbf{A}+\mathbf{B}+\mathbf{C}+\mathbf{D}}$

Keterangan :

A : Sel yang menunjukkan ketidaksetujuan antara kedua penilai

$B$ dan $C$ :Sel yang menunjukkan perbedaan pandangan antara penilai D : Sel yang menunjukkan persetujuan valid antara kedua penilai.

Untuk melihat tingkat pencapaian kriteria validitas isi dapat dilihat pada Tabel 4 berikut.

Tabel 4. Tingkat Validitas

\begin{tabular}{cc}
$\begin{array}{c}\text { Koefesien } \\
\text { Validitas }\end{array}$ & $\begin{array}{c}\text { Tingkat } \\
\text { Validitas }\end{array}$ \\
\hline $0,91-1,00$ & Sangat Tinggi \\
\hline $0,71-0,90$ & Tinggi \\
\hline $0,41-0,70$ & Cukup \\
\hline $0,21-0,40$ & Rendah \\
\hline $0,00-0,20$ & Sangat Rendah \\
\hline
\end{tabular}

2. Validasi Ahli Desain

Validasi desain dilakukan oleh ahli desain pembelajaran. Dalam hal ini akan dilakukan validasi terhadap strukturisasi penjabaran materi. Untuk validasi desain pembelajaran dilakukan dengan menggunakan angket. Dimana melibatkan orang yang ahli dalam bidang desain pembelajaran. Penilaian hasil dari uji ahli desain pembelajaran dihitung dengan Rumus Gregory.

3. Validasi Ahli Media

Validasi media dilakukan oleh ahli media pembelajaran. Dalam hal ini akan dilakukan validasi terhadap ketepatan tata letak bentuk dari penulisan modul. Untuk validasi media pembelajaran dilakukan dengan menggunakan angket, dimana melibatkan orang yang ahli dalam bidang media pembelajaran. Penilaian hasil dari uji ahli media pembelajaran dihitung dengan Rumus Gregory ${ }^{[13]}$. 
4. Validasi Perorangan

Validasi perorangan dilakukan oleh kelas yang mendapat mata pelajaran KKPI.Validasi perorangan dilakukan dengan menggunakan angket. Rumus yang digunakan menghitung persentase masing-masing subyek menurut sebagai berikut.

Persentase $=$

$$
\begin{array}{cl}
\sum \frac{\text { (Jawaban } \mathrm{x} \text { bobot tiap pilihan })}{\mathrm{n} \times \text { bobot tertinggi }} & \mathrm{X} 100 \% \\
\text { Keterangan : } \Sigma & =\text { jumlah }
\end{array}
$$

Selanjutnya, untuk menghitung persentase keseluruhan subjek digunakan rumus :

Keterangan :

$$
\text { Persentase }=(\mathrm{F}: \mathrm{N})
$$

$\mathrm{F}=$ jumlah persentase keseluruhan subjek

$\mathrm{N}=$ banyak subjek

Untuk dapat memberikan makna dan pengambilan keputusan maka digunakan ketetapan terhadap hasil review dan uji coba produk seperti pada Tabel 5.

Tabel 5. Konversi PAP Dengan Skala 5

\begin{tabular}{ccc}
\hline $\begin{array}{c}\text { Tingkat } \\
\text { Pencapa } \\
\text { ian }(\%)\end{array}$ & Kualifikasi & Keterangan \\
\hline $\begin{array}{c}90 \leq \mathrm{P} \leq \\
100\end{array}$ & Sangat baik & Tidak perlu direvisi \\
\hline $\begin{array}{c}75 \leq \mathrm{P}< \\
90\end{array}$ & Baik & Sedikit direvisi \\
\hline $\begin{array}{c}65 \leq \mathrm{P}< \\
75\end{array}$ & Cukup & Direvisi secukupnya \\
\hline $\begin{array}{c}55 \leq \mathrm{P}< \\
65\end{array}$ & Kurang & Banyak hal yang direvisi \\
\hline $\mathrm{P}<55$ & $\begin{array}{c}\text { Sangat } \\
\text { kurang }\end{array}$ & Diulangi membuat produk \\
\hline
\end{tabular}

5. Validasi Kelompok Kecil

Validasi kelompok kecil dilakukan dengan menggunakan angket. Rumus yang digunakan menghitung persentase kelompok kecil adalah rumus (Tegeh \& Kirna, 2010)

6. Validasi Lapangan

Tujuan akhir dalam pengembangan produk e-modul ini adalah untuk mengetahui respon guru dan siswa terhadap pengembangan e-modul dalam pembelajaran KKPI. Untuk melakukan perhitungan analisis data respon guru dan siswa menggunakan statistik deskriptif, dan penyimpulannya didasarkan atas Mean Ideal (Mi) dan simpangan baku ideal (Si). Respons mahasiswa digali menggunakan kuesioner dengan skala Likert 5 (nilai dari 1 sampai 5) yang dianalisis secara deskriptif $^{[15]}$. Rata-rata kelas dari skor respon guru dan siswa dihitung menggunakan rumus:

$$
\bar{x}=\frac{\sum x}{N}
$$

$$
\begin{aligned}
& \text { Keterangan: } \\
& \bar{x}=\text { Rata - rata kelas untuk skor respon } \\
& \text { guru dan siswa } \\
& \sum x=\text { Jumlah skor respon guru siswa } \\
& \dot{N}=\text { Banyaknya guru dan siswa }
\end{aligned}
$$

Sedangkan untuk mencari mean ideal (Mi) dan standar deviasi ideal (Si) digunakan rumus sebagai berikut :

$$
\begin{aligned}
& \text { Mi }=\frac{1}{2}(\text { skor maksimal ideal }+ \\
& \text { skor terendah ideal }) \\
& \quad \begin{array}{l}
\text { Si } \\
=
\end{array} \\
& \quad-\frac{1}{6} \text { (skor terting gi ideal } \\
& \quad \text { skorendah ideal })
\end{aligned}
$$

Data respon siswa terhadap penerapan model pembelajaran Mastery Learning kemudian digolongkan kedalam kategori seperti pada Tabel 6 .

Tabel 6. Kategori Interval ${ }^{[15]}$

\begin{tabular}{lll}
\hline No. & Interval & Kategori \\
\hline 1 & $\mathrm{Mi}+1,5 \mathrm{Si} \leq \bar{x}$ & Sangat Positif \\
\hline 2 & $\begin{array}{l}\mathrm{Mi}+0,5 \mathrm{Si} \leq \bar{x}<\mathrm{Mi}+ \\
1,5 \mathrm{Si}\end{array}$ & Positif \\
& $\begin{array}{l}\mathrm{Mi}-0,5 \mathrm{Si} \leq \bar{x}<\mathrm{Mi}+ \\
0,5 \mathrm{Si}\end{array}$ & Kurang Positif \\
\hline 3 & & \\
\hline 4 & $\mathrm{Mi}-1,5 \mathrm{Si} \leq \bar{x}<\mathrm{Mi}-$ & Negatif \\
\hline
\end{tabular}


$0,5 \mathrm{Si}$

$5 \quad \bar{x}<\mathrm{Mi}-1,5 \mathrm{Si}$

Sangat Negatif

\section{PEMBAHASAN}

Pengembangan e-modul mata pelajaran KKPI memiliki tujuan untuk membantu penambahan sumber belajar, media pembelajaran, meningkatkan kemandirian siswa dan diharapkan dapat meningkatkan pemahaman materi pelajaran KKPI selama proses belajar yang dilakukan tanpa tatap muka dengan guru. Berdasarkan hasil observasi awal yang dilakukan di SMKN 1 Sawan, Terdapat permasalahan proses pembelajaran terkait prakerin. Ketika prakerin berlangsung guru tidak bisa menjelaskan materi kepada siswa, dalam keadaan tersebut siswa dituntut untuk belajar mandiri. Dalam pembelajaran mandiri, sarana pembelajaran yang digunakan siswa selama prakerin hanya berupa website sekolah. Guru hanya memberikan materi dan tugas kepada siswa melalui website sekolah dalam bentuk pdf yang diintregasikan pada menu download beranda web. Hal itu cukup memudahkan siswa untuk mengakses tugas yang diberikan. Namun website tersebut tidak menyediakan forum diskusi untuk komunikasi siswa selama prakerin. Sehingga, siswa yang mengalami kesulitan tidak bisa bertanya apabila ada hal yang tidak dimengerti dari materi dan tugas yang diberikan. Ini mengakibatkan siswa malas mengerjakan tugas. Dengan ini, guru tidak bisa mengontrol proses belajar siswa. Guru tidak bisa memastikan kejujuran siswa dalam mengerjakan tugas. Sehingga proses belajar dan pemberian tugas sering dianggap hanya sebagai formalitas tanpa mengukur pemahaman atau kemampuan siswa itu sendiri.

Selain itu, karena tidak adanya buku pegangan untuk pembelajaran KKPI. Guru hanya menggunakan LKS dan sumber internet untuk mendapatkan bahan ajar. LKS hanya mencakup materi singkat dan terbatas. Bahan ajar atau materi yang dikirimkan guru dalam bentuk pdf tersebut hanya didapat dari sumber internet. Sehingga bahan ajar atau materi yang didapat tidak terstruktur dengan baik. Memang banyak materi yang terdapat di internet dan sumber lainnya mengenai KKPI. Namun hal itu belum sesuai dengan standar kompetensi atau kompetensi dasar pada kurikulum yang diberlakukan oleh sekolah itu sendiri. Pembelajaran mandiri dan satu arah tersebut membuat siswa tidak memiliki inisiatif untuk mencari sumber belajar lain. Siswa cenderung malas mencari sumber belajar lain dan hanya berpatokan pada materi yang diberikan oleh guru. Oleh karena itu dipandang perlu untuk membuatkan media pembelajaran terkait dengan pelaksanaan prakerin yang mengharuskan siswa untuk belajar mandiri dengan permasalahan sumber ajar yang ada dengan pengembangan e-modul berbasis mastery learning. Kelebihan emodul dibandingkan dengan modul cetak adalah sifatnya yang interaktif memudahkan dalam navigasi, dapat menampilkan atau memuat gambar, audio, video dan animasi serta dilengkapi latihan soal yang memungkinkan umpan balik otomatis dengan segera.

Pada penelitian ini modul elektronik disusun berbasis Mastery Learning. Mastery learning atau disebut dengan belajar tuntas adalah pencapaian taraf penguasaan minimal yang ditetapkan untuk setiap unit bahan pelajaran baik secara perseorangan maupun kelompok, dengan kata lain apa yang dipelajari siswa dapat dikuasai sepenuhnya. Dalam pelaksanaannya peserta didik memulai belajar dari topik yang sama pada waktu yang sama pula. Topik tersebut dibagi menjadi unit-unit. Siswa tidak bisa melanjutkan ke tahapan materi selanjutnya apabila belum tuntas pada unit pertama. Siswa yang telah tuntas pada unit pertama mendapat pengayaan sehingga mereka pun memulai mempelajari topik baru pada unit selanjutnya. Hal ini sesuai dengan karakteristik siswa serta karakteristik teknis pembelajaran selama prakerin yang mengharuskan siswa untuk belajar secara mandiri. Sesuai dengan tahapan pada 
desain penelitian yang digunakan model pengembangan PLOMP, tahapan pertama yang dilakukan adalah Investigasi Awal (Prelimenary Investigation). Tahapan ini yaitu tahap analisis terhadap isi kebutuhan, untuk menganalisis segala sesuatu yang dibutuhkan dalam pengembangan, yaitu : (1) analisis karakteristik bidang studi, (2) analisis teknis prakerin, (3) analisis karakteristik siswa, (4) analisis sumber belajar.

Tahapan kedua adalah tahap desain (design) meliputi desain pengembangan emodul, pada tahap ini menentukan Standar Kompetensi (SK), Kompetensi Dasar (KD) dan Indikator pembelajaran yang akan dikembangkan dalam e-modul. Kegiatan penyusunan e-modul meliputi pengumpulan bahan/materi pelajaran, pengetikan bahan ajar, dan penyusunan materi sesuai kompetensi yang diharapkan. Pada tahap desain pengembangan modul peneliti membuat rancangan e-modul yang sesuai dengan kompetensi dasar, indikator dan tujuan pembelajaran. Pada tahap desain pengembangan e-modul peneliti melakukan pengembangan rancangan konten yang akan ditampilkan pada mata pelajaran $\mathrm{KKPI}$.

Tahapan ketiga adalah tahap realisasi (realization/contruction) proses mengembangkan e-modul. Pada tahap ini dilakukan perancangan sistem seperti membuat hak akses masuk ke halaman mata pelajaran, menyusun tampilan masing-masing pengguna (guru dan siswa), mengatur tampilan kegiatan pembelajaran, serta menerapkan materi ke sistem emodul, mengintegrasikan fitur Schoology pada e-modul. Pengembangan pada fitur schoology disesuaikan dengan kerangka emodul yang digunakan dan berisikan implementasi tahapan mastery learning pada e-modul. Tahapan ini sebagai lanjutan kegiatan pada tahap desain. Pada tahap ini dihasilkan prototipe 1 sebagai realisasi hasil perancangan modul. Selain itu peneliti mengembangkan video pembelajaran pada kegiatan pembelajaran tertentu yang nantinya video pembelajaran tersebut dijadikan sumber belajar bagi siswa. Berikut gambar tahap realisasi e-modul pada schoology.

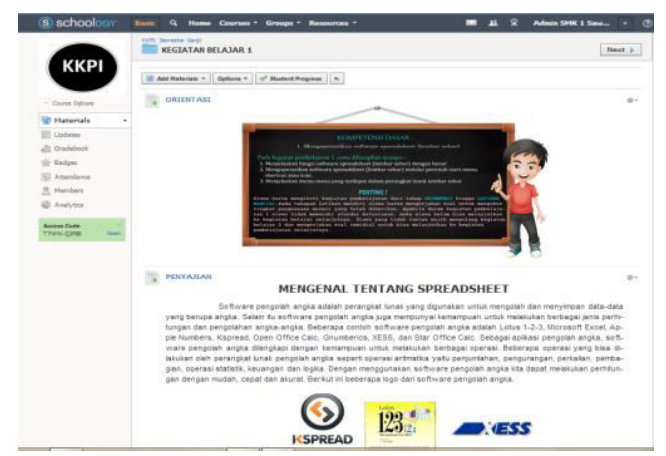

Gambar 3. E-Modul KKPI di Schoology

Tahap keempat adalah Test, Evaluasi, Revisi (Test, Evaluation, Revision), yang dilakukan dengan menguji coba e-modul sesuai dengan peran dan fungsinya dalam proses pembelajaran untuk mengetahui sejauh mana manfaat produk yang dikembangkan. Tahapan uji coba dimulai dari review para ahli, kemudian dilanjutkan dengan uji coba perorangan, kelompok kecil, dan uji lapangan. Uji ahli yang pertama dilakukan adalah uji ahli isi pembelajaran. Uji ahli ini bertujuan untuk mengetahui isi yang terkandung di dalam emodul apakah sudah sesuai dengan konsep pengetahuan atau indikator yang ingin dicapai. Setelah selesai melakukan uji ahli isi, kemudian dilanjutkan dengan uji ahli desain. Uji Ahli desain ini bertujuan untuk mendapatkan validasi e-modul dari segi desain pembelajaran yang terdapat dalam e-modul mata pelajaran KKPI. Setelah selesai melakukan uji ahli media pembelajaran kemudian dilanjutkan dengan uji media pembelajaran. Uji media pembelajaran ini bertujuan untuk mendapatkan validasi dari segi tampilan dan struktur modul yang disajikan dalam emodul KKPI.

Hasil penilaian ahli isi dengan menggunakan uji gregory berdasarkan angket menunjukkan bahwa tingkat pencapaian dari e-modul adalah "SANGAT TINGGI" dan layak untuk dilanjutkan. Hal tersebut mengindikasikan bahwa materi pelajaran yang diimplementasikan dalam emodul sudah relevan untuk digunakan 
dalam pembelajaran KKPI. Karakteristik materi pelajaran KKPI yang cenderung pemahaman konsep dan praktikum, pada emodul sudah dipaparkan dengan bantuan visualisasi melalui gambar dan video sehingga memudahkan pemahaman materi oleh siswa. Hasil angket uji ahli isi pada siklus II berupa revisi uji ahli media pembelajaran pada siklus I.

Hasil penilaian ahli desain pembelajaran dengan menggunakan uji gregory terhadap produk pengembangan e-modul yang terdiri dari kelayakan isi, penyajian, tahap pembelajaran model mastery learning, dan model pembelajaran sudah dinyatakan "SANGAT TINGGI" dan layak untuk dilanjutkan. Hal tersebut mengindikasikan bahwa penerapan model pembelajaran mastery learning dalam e-modul layak untuk digunakan dalam pembelajaran KKPI. Melalui penerapan langkah-langkah model mastery learning dalam pembelajaran membuat siswa menjadi lebih aktif untuk menggali pengetahuannya dan membuat siswa menjadi lebih mandiri dalam proses belajar. Masukan ahli desain seperti materi setiap kegiatan belajar yang harus seimbang dan e-modul bisa diimplementasikan di sekolah. Hasil angket uji ahli isi pada siklus II berupa revisi uji ahli media pembelajaran pada siklus I.

Hasil penilaian ahli media pembelajaran yang terdiri dari penggunaan bahasa dan keterbacaan, grafis, desain tampilan emodul, efektivitas, dan media yang dikembangkan dalam e-modul KKPI telah dinyatakan "SANGAT TINGGI" dan layak untuk dilanjutkan. Media pembelajaran dalam e-modul yang disajikan dalam bentuk teks, gambar, animasi, ataupun video disajikan dengan tepat dan jelas, sehingga siswa dengan mudah dapat belajar dan memahami mata pelajaran KKPI. Hasil penilaian ahli media mengindikasikan bahwa produk e-modul yang sudah dikembangkan layak untuk digunakan dalam pembelajaran KKPI. Masukan dari evaluasi ahli media seperti penggunaan kombinasi warna pada beberapa tampilan grafis diatur kembali dan pertimbangan untuk menguji fitur media yang lainnya seperti badges dan gradebook sudah dilakukan revisi.

Langkah selanjutnya yaitu melakukan uji perorangan, uji kelompok kecil, uji lapangan, uji respon guru, dan uji respon siswa. Subjek uji perorangan adalah tiga orang siswa kelas XI didasarkan pada prestasi mereka yaitu 1 prestasi tinggi, 1 dengan prestasi sedang, dan 1 dengan prestasi rendah. Dari hasil angket uji coba yang diisi oleh masing-masing siswa, satu orang siswa yang memberikan tanggapan sangat baik $(33,3)$, dua orang siswa yang memberikan tanggapan baik $(66,7 \%)$, dan tidak ada siswa yang memberikan tanggapan cukup, kurang, maupun sangat kurang. Rata-rata penilaian siswa adalah $87,00 \%$. Jika dikonversikan ke dalam tabel konversi termasuk dalam kategori baik. Penilaian uji coba perorangan memperoleh hasil baik dari kategori tertinggi yaitu sangat baik. Berdasarkan pengamatan langsung dan wawancara dengan guru pengajar $\mathrm{KKPI}$, responden uji coba perorangan ini adalah siswa kelas $\mathrm{XI}$ yang sudah menguasai pengoperasian komputer dasar namun belum menguasai penggunaan platform schoology, sehingga ketika dilakukan uji coba siswa masih perlu beradaptasi dengan penggunaan e-modul dalam pembelajaran. Solusi pada kegiatan uji coba perorangan ini dilakukan peneliti dengan mengarahkan siswa untuk membaca tutorial pengguna yang sudah terdapat pada e-modul dan mengajarkan cara penggunaannya. Berikut grafik hasil uji coba perorangan.

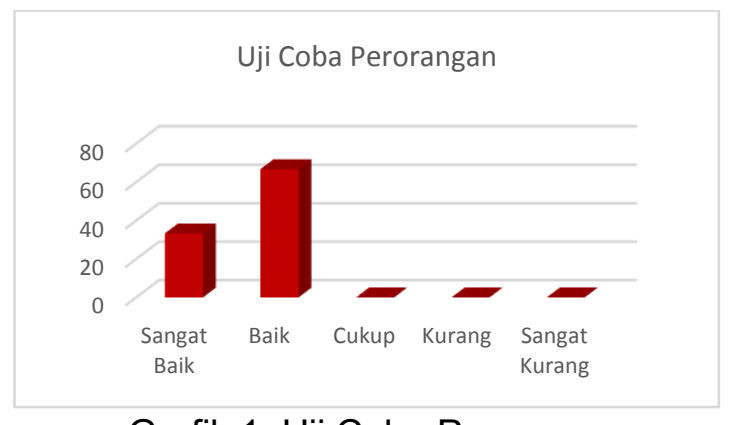

Grafik 1. Uji Coba Perorangan

Setelah uji perorangan selesai dan direvisi, maka dilanjutkan dengan uji kelompok kecil. Uji kelompok kecil 
dilakukan oleh dua belas orang siswa kelas XI. Dari hasil angket uji coba kelompok kecil yang diisi oleh masing-masing siswa, terdapat dua orang siswa memberikan tanggapan sangat baik $(16,67 \%)$, sepuluh orang siswa memberikan tanggapan baik $(83,33 \%)$, dan tidak ada siswa yang memberikan tanggapan cukup, kurang, maupun sangat kurang. Rata-rata penilaian dua belas orang siswa adalah $85,58 \%$. Jika dikonversikan ke dalam tabel konversi termasuk dalam kategori baik. Pada uji coba kelompok kecil terdapat beberapa hal yang menjadi penyebab siswa belum mengerti pengoperasian e-modul berdasarkan pengamatan di lapangan yaitu siswa belum paham penggunaan e-modul dengan menggunakan platform schoology dengan baik, selama ini metode pembelajaran yang dilakukan siswa adalah mendengarkan penjelasan dari guru sehingga ini merupakan pengalaman awal menggunakan pembelajaran berbasis komputer dengan menggunakan e-modul, sehingga membutuhkan penyesuaian dan penjelasan lebih lengkap tentang e-modul. Namun beberapa temuan tersebut sudah dicoba diatasi oleh peneliti dengan mendampingi siswa secara langsung dalam pengoperasian e-modul dan penggunaan tutorial pengoperasian e-modul. Berikut ini grafik uji coba kelompok kecil.

Uji Coba Kelompok Kecil

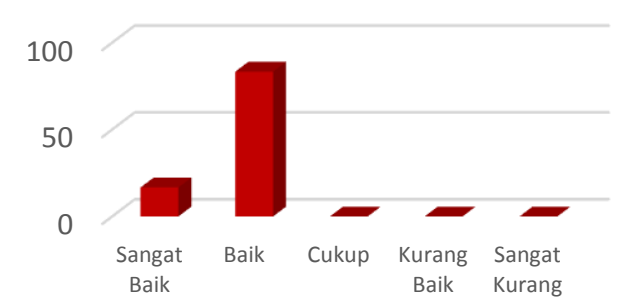

Gambar 2. Uji Coba Kelompok Kecil

Setelah uji coba kelompok kecil selesai dilanjutkan dengan uji lapangan yang dilakukan oleh dua puluh orang siswa kelas XI MM SMKN 1 Sawan. Dari hasil angket uji coba lapangan diperoleh dua orang siswa memberikan tanggapan sangat baik $(10 \%)$, delapan belas siswa memberikan tanggapan baik $(90 \%)$, dan tidak ada siswa yang memberikan tanggapan cukup, kurang, maupun sangat kurang. Rata-rata penilaian keseluruhan responden uji lapangan adalah $82,80 \%$. Jika dikonversikan ke dalam tabel konversi tingkat pencapaian termasuk dalam kategori baik dan sedikit revisi pada emodul. Berdasarkan temuan di lapangan, penggunaan e-modul dalam proses kegiatan belajar mengajar di kelas dapat membantu siswa memahami materi lebih cepat, tanggap, aktif serta meningkatkan interaksi antar guru dan siswa. Melalui isi materi yang disajikan dalam bentuk teks, gambar, dan video dalam e-modul siswa lebih mudah memahami materi dan sangat membantu dalam proses pengumpulan data. Keberhasilan model pembelajaran mastery learning untuk meningkatkan aktivitas belajar siswa disebabkan oleh penerapan model mastery learning yang mampu menumbuhkembangkan keaktifan siswa, kemandirian siswa dalam kegiatan belajar mengajar tanpa didampingi guru serta mampu belajar lebih disiplin dan bertanggung jawab dalam pengerjaan setiap tugas maupun soal yang diberikan. Berikut ini grafik hasil uji lapangan.

\section{Uji Coba Lapangan}

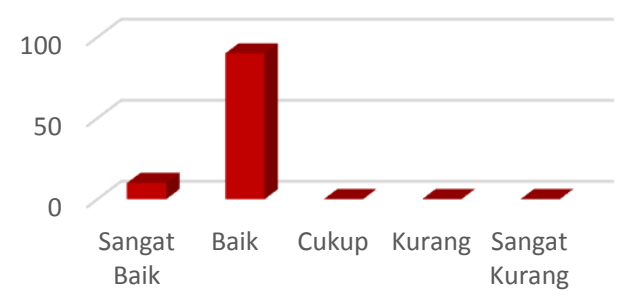

Grafik 3. Uji Lapangan

Setelah hasil uji lapangan selesai dilakukan, selanjutnya dilakukan pengambilan respon guru terhadap pengembangan e-modul pada mata pelajaran KKPI. Uji respon guru dilakukan oleh satu orang responden yaitu lbu Putu Soni Ermawati dan memperoleh rata-rata sebesar 45, jika dikonversikan ke dalam tabel kriteria penggolongan respon maka hasilnya termasuk dalam kategori sangat positif. Proses uji selanjutnya dilakukan dengan pengambilan respon siswa. Subjek 
uji coba respon siswa adalah terdiri dari 20 orang siswa kelas XI yang telah belajar menggunakan e-modul. Hasil angket respon siswa terhadap pengembangan emodul KKPI memperoleh rata-rata sebesar 65,70 , jika dikonversikan ke dalam tabel kriteria penggolongan respon maka hasilnya termasuk dalam kategori positif. Berdasarkan hasil respon guru dan siswa dapat dikategorikan membantu siswa dalam memahami mata pelajaran KKPI dan berhasil mengatasi permasalahan yang ada dalam proses belajar mengajar yang sudah dijelaskan sebelumnya. Dari perolehan respon tersebut ini mengindikasikan bahwa media pembelajaran dapat meningkatkan motivasi siswa untuk belajar sehingga mendapat hasil belajar yang optimal. Hal ini juga dibuktikan pada penelitian Ananda, 2014 yaitu Pengembangan E-Learning Berbasis Schoology Pada Mata Pelajaran IPA Kelas VIII Di SMP Negeri 1 Seririt. Yang menyatakan nilai rata-rata siswa setelah menggunakan media $(87,03)$ lebih tinggi dibandingkan sebelum menggunakan media $(59,24)$.

Berdasarkan pembahasan di atas, penilaian-penilaian yang dilakukan oleh ahli isi, ahli desain pembelajaran, ahli media, uji coba perorangan, uji coba kelompok kecil, uji lapangan, maupun hasil respon guru dan siswa termasuk dalam kategori baik dan mendapat respon positif. Berdasarkan penilaian tersebut, secara garis besar pengembangan e-modul berbasis model pembelajaran mastery learning pada mata pelajaran KKPI untuk siswa kelas XI di SMKN 1 Sawan telah menunjukkan adanya keberhasilan dan layak digunakan sebagai sumber belajar untuk siswa kelas XI SMKN 1 Sawan. Hal ini didukung pula dengan beberapa pernyataan siswa yaitu keberadaan e-modul KKPI sangat membantu dalam proses pembelajaran, emodul membuat siswa lebih antusias dalam belajar KKPI, maupun memudahkan siswa memahami materi lebih cepat dan sangat efektif dalam pelajaran. Melalui penerapan e-modul KKPI ini diharapkan dapat membantu guru selama proses pembelajaran langsung maupun tidak langsung dan masalah selama proses pembelajaran terkait sumber belajar mampu teratasi, serta mampu membuat peserta didik aktif, mandiri dalam proses belajarnya, bertanggung jawab dan disiplin .

E-modul KKPI yang diterapkan di SMKN 1 Sawan dengan subjek uji coba yaitu siswa kelas XI MM dan guru pengajar KKPI memiliki beberapa kelebihan dan kendala yang ditemukan, adapun kelebihan dari e-modul KKPI dengan menggunakan platform schoology yang ditemukan yaitu. 1) E-modul KKPI memudahkan siswa dalam belajar mandiri sesuai dengan kurikulum KTSP, 2) E-modul KKPI meningkatkan kemandirian siswa dalam mencapai nilai ketuntasan melalui tahapan-tahapan model mastery learning, 3) E-modul menambah semangat siswa dalam belajar KKPI, karena pembelajaran dengan menggunakan e-modul membawa siswa pada suasana pembelajaran baru yang belum pernah siswa dapatkan sebelumnya sehingga rasa ingin tahu siswa dalam belajar dengan menggunakan e-modul membuat mereka menjadi lebih bersemangat dalam belajar. Sedangkan kendala yang ditemukan selama melakukan uji coba e-modul KKPI yaitu siswa belum menguasai penggunaan e-modul dengan menggunakan platform schoology, sehingga ketika dilakukan uji coba siswa masih perlu beradaptasi dengan penggunaan e-modul dalam pembelajaran. Solusi pada kegiatan uji coba ini dilakukan peneliti dengan mengarahkan siswa untuk membaca tutorial pengguna yang sudah terdapat pada e-modul dan mengajarkan cara penggunaannya.

\section{SIMPULAN}

Hasil rancangan dan realisasi Pengembangan E-Modul Berbasis Mastery Learning Pada Mata Pelajaran KKPI Kelas XI menggunakan tahapan model mastery learning sudah dinyatakan berhasil diterapkan. Respon terhadap Pengembangan E-Modul Berbasis Mastery Learning yang didapatkan termasuk dalam kategori sangat positif. Sedangkan untuk respon siswa terhadap pengembangan emodul KKPI dari rata-rata yang didapatkan termasuk dalam kategori positif. Dari 
perolehan respon tersebut ini mengindikasikan bahwa media pembelajaran dapat meningkatkan motivasi siswa untuk belajar sehingga mendapat hasil belajar yang optimal. Hal ini juga dibuktikan pada penelitian Ananda, 2014 yaitu Pengembangan E-Learning Berbasis Schoology Pada Mata Pelajaran IPA Kelas VIII Di SMP Negeri 1 Seririt. Yang menyatakan nilai rata-rata siswa setelah menggunakan media $(87,03)$ lebih tinggi dibandingkan sebelum menggunakan media $(59,24)$.

Berdasarkan pengamatan penulis, terdapat beberapa hal yang dapat dijadikan bahan pertimbangan untuk ditindak lanjuti. 1) Bagi pengembang e-modul selanjutnya agar dapat mengatur e-modul lebih user friendly atau mudah digunakan oleh pengguna yang masih belum terbiasa dengan pembelajaran berbasis komputer. Selain itu, dapat mengatur agar setiap tahapan pembelajaran Mastery Learning terdapat fitur yang bisa memberikan tantangan baik berupa games atau bentuk lainnya agar siswa tidak merasa bosan ketika sedang belajar dengan menggunakan e-modul. 2) Pengembangan e-modul pada mata pelajaran KKPI ini hanya dilakukan uji coba pada kegiatan belajar 1, jadi diharapkan untuk peneliti selanjutnya agar dapat melakukan uji coba secara keseluruhan dari e-modul ini. 3) Produk e-modul berbasis model pembelajaran mastery learning pada mata pelajaran KKPI untuk siswa kelas XI di SMKN 1 Sawan yang dikembangkan belum sampai pada tahap implementasi. Oleh karena itu, perlu diadakan pengkajian lebih lanjut mengenai efektivitas penggunaan emodul berkaitan dengan pengukuran hasil belajar siswa menggunakan e-modul ini melalui penelitian eksperimen.

\section{REFERENSI.}

[1] Sadiman et.al. (2005). Media Pendidikan. Jakarta: PT. Raja Grafindo Persada.

[2] Sugihartini, Pengembangan

N. (2017). E-Modul Mata
Kuliah Strategi Pembelajaran. Jurnal Pendidikan Teknologi dan Kejuruan, 221.

[3] Usman, M. (1993). Upaya Optimalisasi Kegiatan Belajar Mengajar. Bandung: Remaja Rosdakarya.

[4] Dafid. (2011). Penelitian Belajar Tuntas (Mastery Learning). Skripsi Tidak Diterbitkan.

[5] Bayu . (2015). Penelitian Pengembangan berbasis Schoology Bahasa Indonesia Kelas X di SMA Negeri 4 Singaraja.

[6] SMK Direktorat Pembinaan. (2004). Kurikulum SMK.

[7] Wena, M. (2009). Strategi Pembelajaran Inovatif Kontemporer. Jakarta: Bumi Aksara.

[8] Anwar, I. (2010). Pengembangan Bahan Ajar Bahan Kuliah Onlline. Bandung : Direktori UPI.

[9] Vembrianto. (1985). Pengantar Modul. Yogyakarta: Pendidikan Paramita.

[10] Gunadharma. (2011). Pengembangan Modul Elektronik sebagai Sumber Belajar Untuk Mata Kuliah Multimedia Design. Jurusan Teknologi Pendidikan, Fakultas IImu Pendidikan, Universitas Negeri Jakarta, Skripsi (tidak diterbitkan).

[11] Cecep, K., \& Bambang, S. (2013). Media Pembelajaran Manual dan Digital. Bogor: Penerbit Ghalia Indonesia.

[12] Candiasa. I.M (2011). Pengujian Instrumen Penelitian Disertai Aplikasi ITEMAN BIGSTEPS. Singaraja:Unit Penerbitan Undiksha 
[13] Gregory, R.J (2000). Phsychological Testing. United States of America : Allyn \& Bacon Inc.

[14] Tegeh, I. M., \& Kirna, I. M. (2010). Metode Penelitian Pengembangan Pendidikan. Singaraja: Undiksha.
[15] Agustini, K. (2013). Pengaruh Penggunaan Simulasi Binary Tree Berbasis CAI Terhadap Motivasi dan Hasil Belajar Matematika Diskrit Mahasiswa Jurusan PTI Undiksha. Jurnal Pendidikan Indonesia, Vol. 2, No. 1. 